\title{
Projected inundations on the South African coast by tsunami waves
}

\author{
Hayley C. Cawthra, F. Wilhelm van Zyl \\ Council for Geoscience, Bellville, 7535, Cape Town, South Africa, hcawthra@geoscience.org.za
}

DOI: $\underline{\text { http://dx.doi.org/10.4314/sajg.v4i2.4 }}$

\begin{abstract}
Historical and recent evidence recorded along the South African coast suggests that five tsunami events have occurred since 1960. These were mostly associated with trigger mechanisms associated with sources of remote submarine seismicity along far-field subduction zones and local atmospheric disturbances (meteotsunami). The passive margin of the South African West Coast, and the broad Agulhas Bank spanning the South- and Southeast coasts, have contributed to an increased susceptibility to inundation of waves in the adjacent low-lying coastal areas in these regions. In the published models and empirical studies for South Africa, the bathymetry and orientation of Port Elizabeth Bay is seen to amplify effects of a tsunami wave. Other regions including the Cape Town and St Helena Bay areas are also vulnerable to coastal inundation through the data generated in this study. The methodology presented here provides a simple means of determining the susceptibility of coastal areas to significant inundation by far-field tsunamis.
\end{abstract}

\section{Introduction}

Tsunamis are waves generated by the large and sudden forced displacement of the seafloor, with characteristics intermediate between tides and swell waves (Løvholt et al., 2009). Although tsunamis are relatively infrequent (an average of 5-10 events reported globally per year) they represent a serious threat to coastal communities, as demonstrated by the devastating effects of the 2004 Indian Ocean tsunami (NGDC, 2011) and the 2011 Tohoku Earthquake Tsunami (Gokun and Hoshimira, 2012). Waves have the potential to inundate significant areas onshore depending on the local topography and bathymetry, as well as the hydrostatic and hydrodynamic force of the wave (US NRC, 2009). Waves generated by rapid displacement along submarine faults are referred to as tsunamis generated by remote submarine seismicity and these are the most devastating (NGDC, 2011). Tsunamis can, however, also be generated by various mechanisms including submarine earthquakes and landslides, collapsing/exploding volcanoes, pyroclastic flows, caldera collapse, terrestrial rock falls, asteroid impacts, meteoric conditions and nuclear explosions (Okal and Synolakis, 2004; Grilli and Watts, 2005; US NRC, 2009).

When the tsunami is generated, it propagates in the open sea as a gravity wave (McCloskey et al., 2008) with speeds of several hundred kilometres per hour, and may therefore reach coastlines distant from the earthquake within a relatively short time. The wave decelerates as it approaches the shoreline, causing an increase in amplitude as the wave energy is compressed (NGDC, 2011). 
Because of its comparatively large wave-length, the tsunami may travel far inland compared to wind waves and swells, and because of its relatively short period, it inundates much faster than tidal waves and storm surges (Løvholt et al., 2009). When the tsunami inundates land, flow velocities accelerate, giving the tsunami the competency to move large objects (automobiles, trees, etc), erode the landscape and destroy buildings. The tsunami is lethal to life both due to trauma suffered from impacts by suspended debris and flotsam, as well as from drowning. Generally, tsunamis cause damage to most coastal structures; however, buildings of poor quality are particularly vulnerable to total destruction. The tsunami is most destructive close to the shoreline where the flow velocity and wave loads are largest. Tsunami deposits are well documented from modern, historical and late Quaternary times (Scheffers and Kelletat, 2003).

As these natural events are unavoidable, risk maps can help to estimate the recurrence time of future possible events and to calculate the maximum inland penetration of impacting waves. These factors are critical in establishing evacuation/intervention plans. Various global studies regarding tsunami flooding have been produced using mathematical models to simulate the tsunami approaching the coastal area (e.g. Mader, 1974; Synolakis, 1991; Tanioka and Satake, 1996; Titov and Synolakis, 1998; Piatanesi and Tinti, 2002; Tinti and Armigliato, 2003; Weiss et al., 2006). In South Africa, the known published numerical datasets which model tsunamis were produced by Kijko et al. (2008), Okal and Hartnady (2009) and Luger (2010). These models use differential equations considering boundary conditions that take into account some approximation with respect to local coastal features. Morphological data, including topography and bathymetry, is considered key in understanding the response of the affected coastal zone (Pignatelli et al., 2009).

Here we consider the effect of tsunamis in a far-field location relative to most documented source areas. In the paper we consider the South African coastline in the identification of coastal areas vulnerable to a significant inundation by tsunami waves, using GIS techniques and drawing on existing models. Consequently, this study describes the development of site-specific tsunami inundation models using coastal topography/bathymetry. To date the models have not been validated by geological sampling for historical tsunami deposits. The work presented in this paper presents the results of a pilot study to identify vulnerable coastal areas to tsunami inundation in South Africa and a simple, reproducible methodology.

\section{Background and context}

\subsection{Study area}

The South African coastline is situated on a stable intraplate continental margin, in a trailing edge, low tectonoseismic environment (De Swardt and Bennett, 1974, Goedhart et al., 2007). Global localities with low-frequency background seismicity have been reported to share a similar geological setting (Fernandez and Shapira, 1989). The modern neotectonism is a result of the complex early geodynamic history of southern Africa and modern recorded seismicity is interpreted to prevail along relict lineaments of crustal weakness (de Beer, 1983; Partridge and Maud, 2000; Goedhart et al., 2007; Roberts, 2008).

Fernandez and Shapira (1989) and Shapira et al. (1989) summarised the modern and historical distribution of seismicity of South Africa (Figure 1). Amplified seismicity is centred around Cape 
Town linked to the intense fracturing of the Cape Fold Belt syntaxis northeast of the city (de Beer, 1990), where faults have triggered at least $M_{w} 6.3$ events (Theron, 1974). Loci of seismicity along the East Coast surround the Mzimvubu River valley suggested to be associated with the Melville Thrust in the Namaqua-Natal province and shear zones of the Margate Terrain (Thomas, 1989). To the north, in the vicinity of Sodwana Bay, the Thukela Thrust Front is linked to modern seismicity. The Ceres-Kango-Baviaanskloof-Coega fault forms part of the Ceres-Baviaanskloof-St. Croix (CB-S) fault system, which traverses the Cape Fold Belt and extends offshore as the St Croix fault, joining the Agulhas-Falklands Fracture Zone (AFFZ) (Goedhart et al., 2007). Holocene faulting in this region suggests that the entire southern coast could be considered vulnerable to future seismic events (Goedhart et al., 2007).

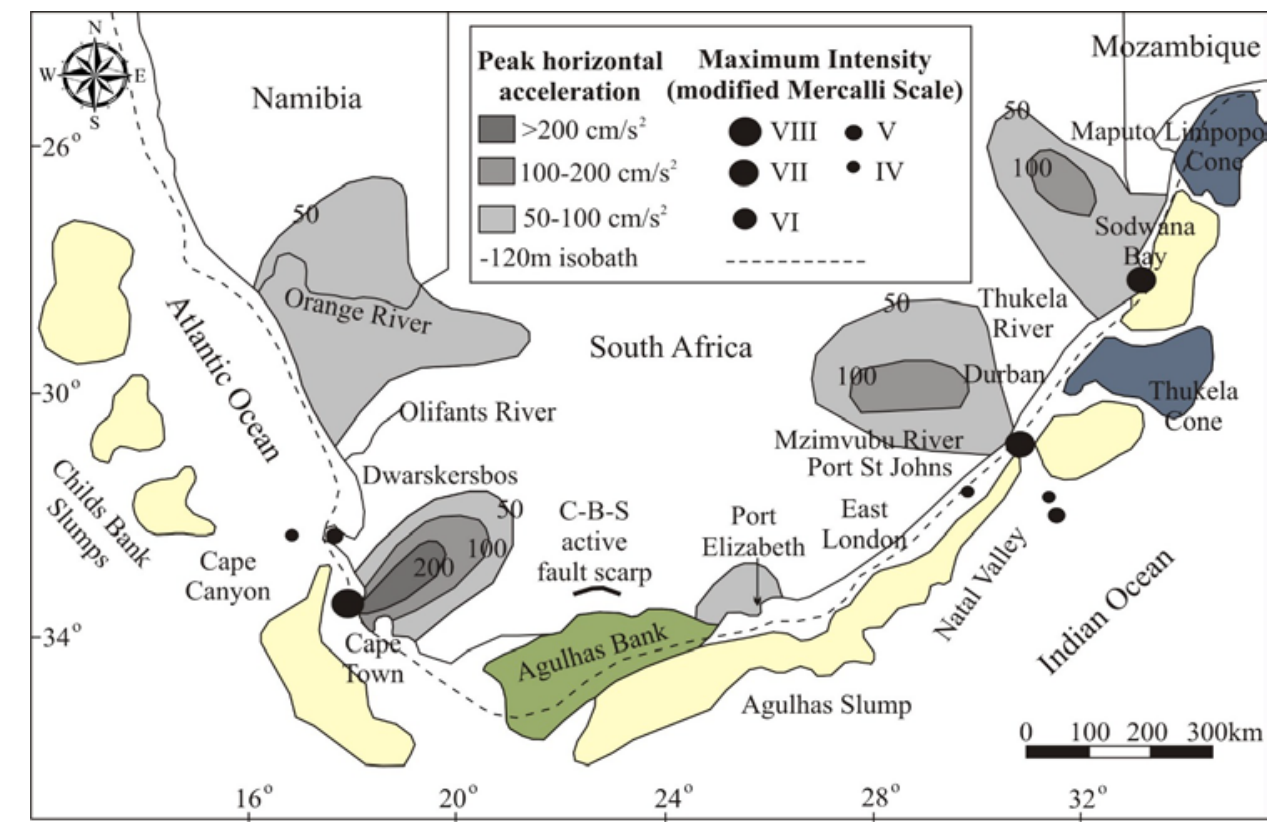

Figure 1. Historical seismicity illustrated by contours of $10 \%$ probability, and historical earthquake location and magnitude (after Fernandez and Shapira, 1989) and offshore slumps of South Africa (modified from Roberts, 2008). The West Coast slumps lie further offshore as a result of the wide shelf in this region. Abbreviations: C-B-S: Ceres-Baviaanskloof-St Croix fault.

\subsection{Tsunami threat in South Africa}

Løvholt et al. (2009) did not demarcate South Africa as a global site of high tsunami risk ( $<2 \mathrm{~m}$, Figure 2) but numerical modelling to predict the sources, frequency and amplitude of tsunamis that could affect the South African coastal zone carried out by Hartnady (2005), Kijko et al. (2008), Okal and Hartnady (2009) and Luger (2010) confirm the need for it to be considered. The primary focus of previous studies in southern Africa has been on the threats presented by submarine seismicity, volcanicity and submarine slumps off the East Coast (Hartnady, 2005). A study by Roberts (2008) further considers submarine slumps along the South and West coasts of South Africa, cosmic impacts and the tsunamigenic threat presented by major submarine rockfalls and landslides. The most imminent tsunami threat to the South African coast is posed by megaearthquakes associated with the subduction zones of the Indian Ocean. Convergent plate-boundaries at the Sunda Trench of the Sumatra-Andaman subduction zone between Indonesia and Burma (McCloskey et al., 2008), the Makran Trench bordering Pakistan and Iran (Hartnady, 2005) and the South Sandwich Islands of the Atlantic (Kijko et al., 2008) are also identified as potential tsunami 
sources that could affect South Africa. Port Elizabeth and Durban along the East Coast are the most vulnerable to such events.

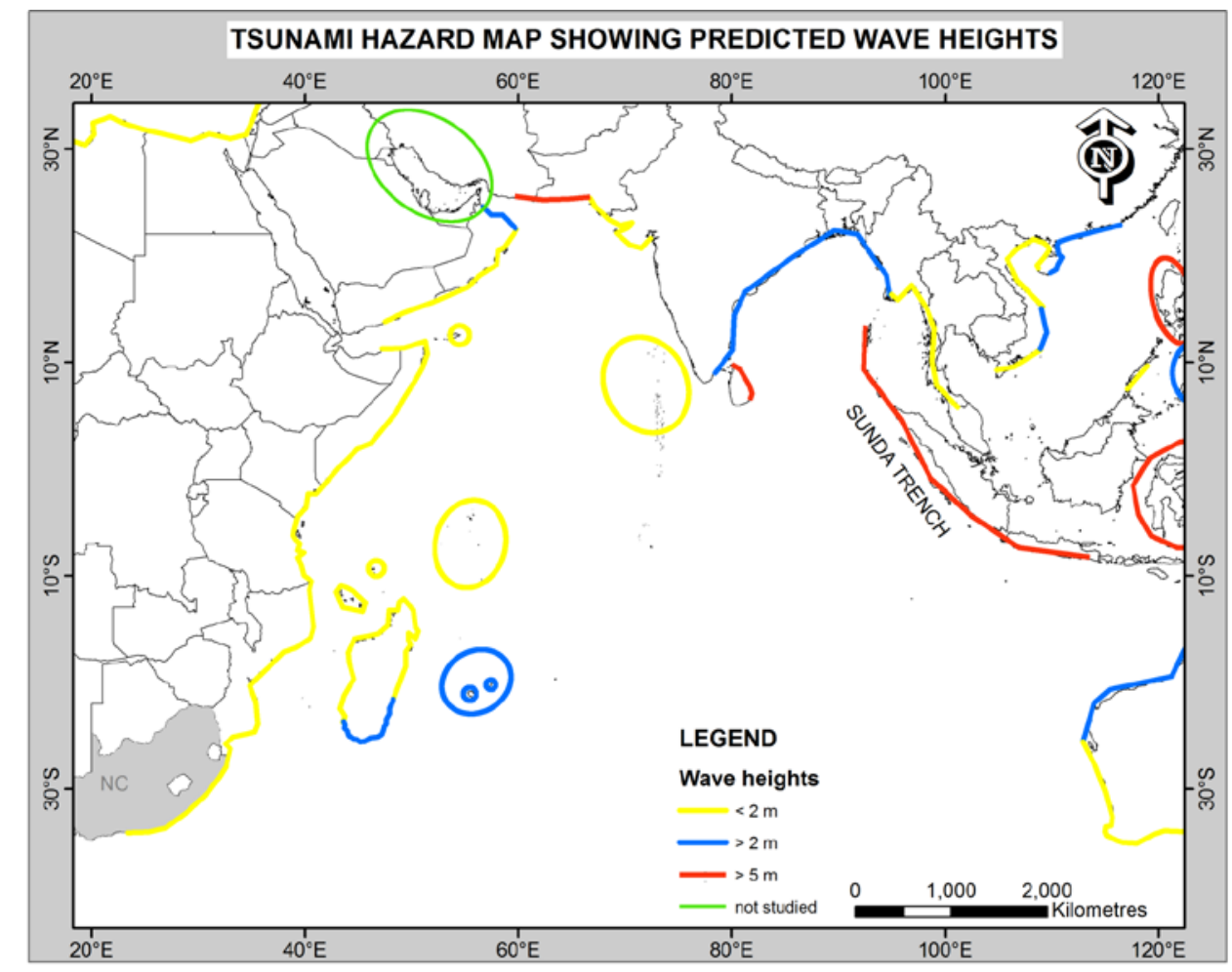

Figure 2. Global tsunami hazard map showing the maximum wave heights predicted (UNISDR, 2009).

The results of hydrodynamic simulations by Okal and Synolakis (2008) indicate that the distribution of maximum amplitudes in the Indian Ocean Basin is principally controlled by the classical effect of source directivity, and additionally by refraction and focusing along bathymetric features on the seafloor. In addition, tide gauge response to tsunamis is greatly influenced by largescale local bathymetry of continental shelves (van Dorn, 1987). Luger (2010) applied the MIKE hydrodynamic model of the Danish Hydraulics Institute to investigate combinations of fault parameters and tsunami wave propagation from the above-mentioned sources, reaching the Eastern Cape coast, the Southern Cape coast and the West Coast of South Africa. In the published models and empirical studies for South Africa, the bathymetry and orientation of Port Elizabeth Bay is seen to amplify the tsunami, particularly in the western corner of the bay and inside the two ports (Luger and Harris, 2010), on the continental shelf edge offshore of Cape Town, and at St Helena Bay on the west coast (Okal et al., 2014).

\subsection{Historical record of global tsunami events documented in South Africa}

\section{Chilean earthquake and tsunami}

The earliest reported tsunami caused by remote submarine seismicity that affected South Africa was triggered by the $\mathrm{M}_{\mathrm{w}} 9.5$ earthquake off the south central Chilean coast on 22 May 1960 (Berkman and Symons, 1964). The Chilean event was recorded globally and in southern Africa tidal irregularities associated with this event were recorded at Mossel Bay and Lüderitz (van Dorn, 1987). 


\section{Dwarskersbos event}

A tsunami was reported in the West Coast village of Dwarskersbos, $170 \mathrm{~km}$ northwest of Cape Town in the early hours of 27 August 1969. Die Burger (2005) published eyewitness accounts of this event and it was noted that the wave with a maximum run-up of $2.9 \mathrm{~m}$, concentrated on an extremely short segment of coastline, less than $2 \mathrm{~km}$ in length, flooding houses and moving motor vehicles (Okal et al., 2014).

\section{West Coast meteotsunami}

A series of surges were reported on the West Coast on 20 - 21 August 2008, observed in harbours and estuaries (SAWS, 2008). The sea receded to below the Mean Low Water level and surged to beyond the Mean High Water level. The effects were greatest at Lamberts Bay, St Helena Bay and Hout Bay (Okal et al., 2014). Along the West Coast during this event 60-15 minute period waves ranged in amplitude between 0.5 and $1.5 \mathrm{~m}$ (SAWS, 2008).

\section{Indian Ocean Tsunami}

The Indian Ocean Tsunami on 26 December 2004 was generated by a magnitude 9.3 earthquake, causing a rupture in excess of $1200 \mathrm{~km}$ in length extending from Sumatra to the Andaman Islands (Billham et al., 2005; Kruger et al., 2005). The Sumatra-Andaman earthquake of 26 December 2004 has induced great awareness of tsunami risk in the Indian Ocean (IOWTS, 2007), including along the South African coastline and within the South African scientific community. The 2004 Indian Ocean Tsunami was recorded by South African tide gauges on the eastern and southeastern seaboard with a maximum wave height at Port Elizabeth measuring $2.7 \mathrm{~m}$ above Mean Sea Level. Rabinovich and Thomson (2007) suggest that the actual wave height was even higher but the wave crest had been truncated on the instrumentation. Smaller waves inundated Richards Bay (1.5 m), East London $(1.3 \mathrm{~m})$ and Mossel Bay $(1.6 \mathrm{~m})$. Maximum recorded wave heights on the Atlantic seaboard were $0.75 \mathrm{~m}$ in Cape Town and $0.5 \mathrm{~m}$ above Mean Sea Level at Port Nolloth. Although the effects of the Indian Ocean Tsunami of 2004 were not considered to be too significant in South Africa, Okal et al. (2009) show that a culmination of unfavourable conditions (for example, highest astronomical tide) could raise run-up levels and potentially cause serious damage along the South African coast. The Sumatran-Andaman event of 2004 has demonstrated that seismogenic teletsunamis generated at remote localities can impinge on the South African coastline.

\section{Sumatran earthquake}

At 11:10:26 UTC on 12 September 2007, a $\mathrm{M}_{\mathrm{w}} 8.4$ earthquake occurred 130km southwest of Bengkulu, Sumatra, Indonesia (IOTWS, 2007; USGS, 2011). The earthquake was triggered by movement along a thrust fault on the boundary of the Australian and Sunda plates. This is a seismically active region, having experienced four earthquakes exceeding magnitudes of 7.9 in the last decade (USGS, 2011). The IOC sea level observation station at Port Elizabeth showed tsunami activity starting at 23:30 local time (12 hours, 20 minutes after the earthquake), consistent with Tsunami Travel Time modelling carried out through the NOAA NGDC, the ITIC and UNESCO IOC. The effect of this tsunami was observed on tide gauge data from the Port Elizabeth Harbour after the event but no significant impacts were reported. 


\section{Methods}

\subsection{GIS data manipulation}

In this study we identified areas predicted to be affected by local and distant tsunami sources (outlined previously), considered the bathymetry and coastal topography of South Africa and derived a Digital Elevation Model (DEM) from the best available bathymetric and topographic data sources. Using ArcGIS, we grouped elevation bands for SRTM data. 0-5m, 5-10m, 10-20m and reclassed them to $5,10,20 \mathrm{~m}$. All values below these elevations were flooded and the resultant horizontal inundation measured.

Maps of the South African coastline indicating the spatial distribution of tsunami run-up on vulnerable low-lying areas were produced and three examples of scenarios presented for 5, 10 and $20 \mathrm{~m}$ run-up values. The maximum horizontal inundation for each 'vulnerable area' was tabulated. The three values were selected based on a minimum value of $5 \mathrm{~m}$, indicating the case of a high tide coupled with a run-up of $3 \mathrm{~m}$. This was extended to include values of 10 and $20 \mathrm{~m}$ as arbitrary values for a South African context, but considering global run-up models. These data therefore display DEMs for wave run-up and inundation onto dry land at the coast.

\subsection{Terminology}

Tsunami height refers to the height of the wave until it reaches the shoreline. Maximum water level (hereinafter referred to as inundation) is the maximum penetration of the wave, and run-up height (run-up) is the altitude above sea level of the point of maximum penetration where inundation is measured. These three parameters are considered relative to Mean Sea Level (MSL) and exclude astronomical tides.

\section{Results: potential inundation models for vulnerable areas on the South African coast}

Inundation modelling attempts to recreate the tsunami generation in deep or coastal waters, wave propagation to the impact zone and inundation along the study area. To replicate accurate wave dynamics during the inundation computations, high-resolution bathymetric grids are used (NOAA, 2011). The high-resolution datasets require constant upgrades as better data becomes available and coastal changes occur. Projected run-up distribution models for South Africa as part of an initial PTHA for our coastline are presented in Figure 3A and B and Table 1 as a first guide to identify vulnerable low-lying coastal areas. Numerical values are tabulated below. The topographic data used in the production of the Digital Elevation Models for South Africa is SRTM data with a resolution of $90 \mathrm{~m}$. 
Table 1. Maximum measured horizontal inundations and approximate areas (in $\mathrm{km}^{2}$ ) based on $5 \mathrm{~m}$, $10 \mathrm{~m}$ and $20 \mathrm{~m}$ examples of tsunami run-up. The values are rounded to whole numbers.

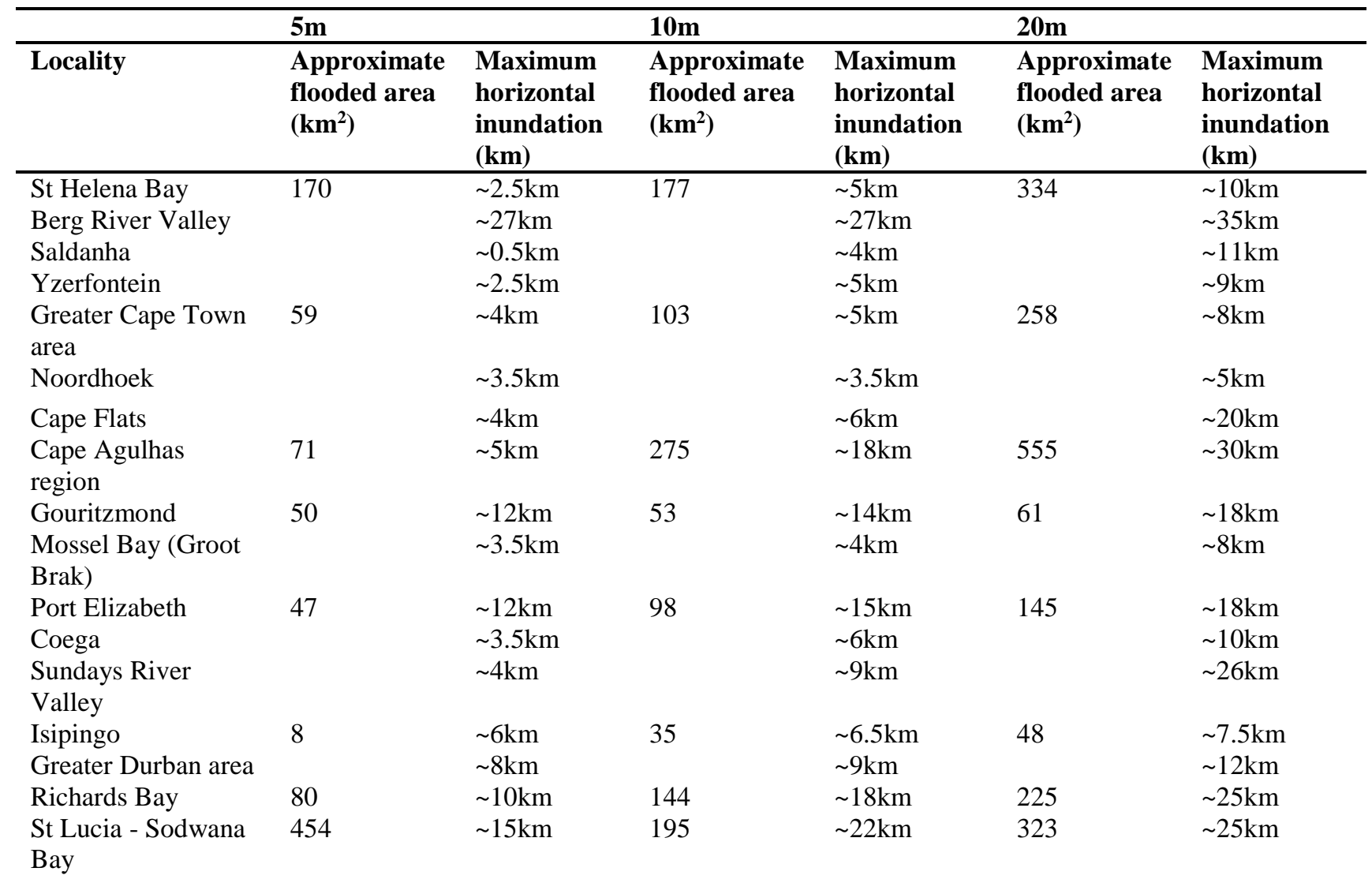

\section{Discussion}

This study aims to provide an overview of areas susceptible to tsunami inundation in South Africa. Using these data, the next phase of work will involve the initiation of a programme to drill these low-lying coastal areas of marine terraces to determine whether tsunamigenic sedimentary deposits exist in the palaeo record. Preserved sedimentary sequences can be differentiated from storm deposits depending on the preservation of bedforms indicative of long period waves (Shiki et al., 2008), washover deposits, repeated turnover of flow directions, and lagoon deposits (Fujiwara and Kamataki, 2007).

\subsection{Geomorphology of rocky coastlines of South Africa as limiting factors or coastal deposits?}

The preservation of tsunami deposits in the coastal geological record is a function of the morphology of the pre-tsunami landscape and accommodation space (Nichol et al., 2010). Mapping damage of global tsunamis, most recently the March 2011 Tohoku Earthquake Tsunami (e.g. Gokun and Hoshimira, 2012) have confirmed that areas most adversely affected within the inundation zone lie in low-gradient coastal areas. However, the inundation distance in this case was relatively short (generally up to $2 \mathrm{~km}$ ) as a result of a steep onshore gradient, except along rivers, where it was significantly longer (Mori et al., 2012). Estuaries, wetlands and lagoons of the coastal zone located behind low coastal barriers can host a record of tsunami history along source-bordering coasts and have been documented in the US Pacific Northwest, Chile, Japan and New Zealand (Peters et al., 2007; Atwater et al., 2005; Minoura et al., 1994; Goff et al., 2001; Nichol et al., 2010, respectively). Considerable scope remains to explore the sedimentary record around South Africa 

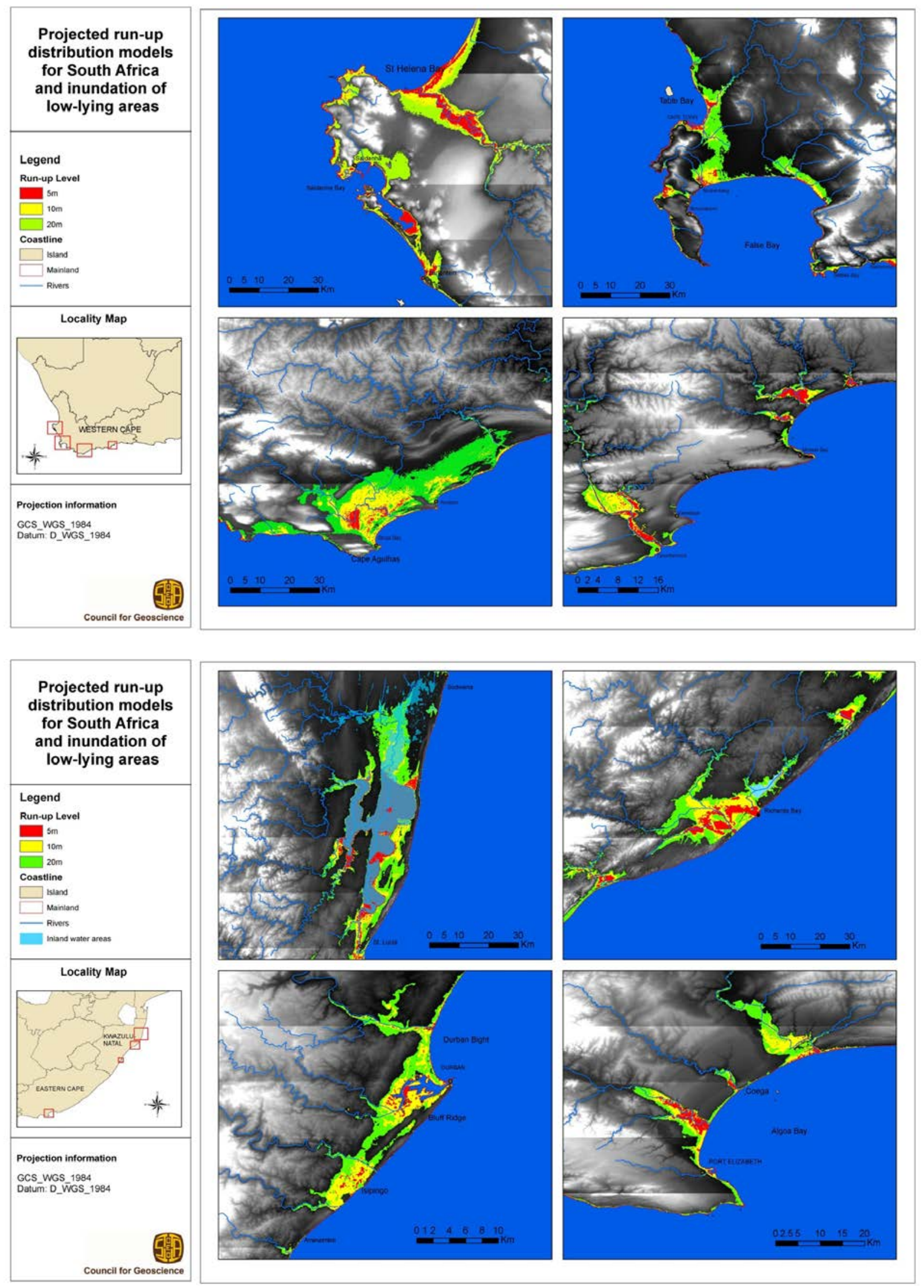

Figure 3. In the upper panel, examples of projected run-up models for the Western Cape of South Africa are presented. The extent of horizontal coastal inundation is notable. The lower figure provides examples of projected run-up models for the Eastern Cape and KwaZulu-Natal Provinces of SA. Horizontal coastal inundation is notable. 
for tsunami evidence at localities that are situated within the path of known tsunamis. Although Holocene to present storm deposits have been documented in South Africa (e.g. Salzmann and Green, 2012), no interpreted tsunami deposits have been described along this coastline.

Coastal dunes can provide significant protection to tsunami inundation, as observed along the Sri Lankan coast following the 2004 Indian Ocean Tsunami (Liu et al., 2005; Morton et al., 2008). Run-ups from similar sized tsunamis can be variable because of the influence of the shapes of coastlines. One coastal area may see no damaging wave activity while in another area, destructive waves can be large and violent. Low-lying coastal areas characterised by broad coastal plains are particularly susceptible to tsunami inundation as would be broad river valleys and estuaries.

\subsection{Continental shelf morphology as an influencing factor in tsunami magnitude}

The role of bathymetry is such that large-scale bathymetric features shoaling from the seafloor (such as islands or submerged rocky outcrops) provide a buffer to coasts. Tsunamis generated in relatively shallow water have a relatively small potential energy and do not produce large amplitude waves (McCloskey et al., 2008). Offshore bathymetry that is smooth on wide, featureless parts of a shallow ramping continental shelf will, however, have increased probability of sustaining large amplitude tsunamis. In South Africa, this implies that the West Coast and the South Coast in the vicinity of the Agulhas Bank are the most susceptible areas to tsunamis; and this is confirmed in the models discussed.

\section{Conclusions}

We have presented a simple means of determining coastal areas susceptible to a significant inundation by far-field tsunamis. This work presents the first phase of an anticipated investigation into palaeo-tsunami deposits on unbarred parts of the South African coast. The areas investigated were selected based on existing models, and the run-up values can be modified accordingly. In a South African context, regions with a broad coastal plain, generally also bordered by a broad continental shelf, are most susceptible to visible effects of far-field tsunamis. The impact of inundation is considered more severe in urban centres along the coastline, such as the cities of Cape Town, Port Elizabeth and Durban, compared to the more sparsely populated areas between. The South- and Southeast Coasts are bordered by a shallow ramping shelf but significant dunes along this coastal plain and the three larger cities mentioned above likely act as buffers to dissipate energy of a high-energy wave.

\section{Acknowledgements}

This work formed part of the South African Geological Hazards Observation System (SAGHOS) joint Department of Science and Technology - Council for Geoscience project. Drs Jeanine Engelbrecht and Chiedza Musekiwa are gratefully acknowledged for support. The reviewers, Prof John Compton and Mr Coenie de Beer, are thanked for thoughtful comments and improvements to this manuscript. 


\section{References}

Atwater, BF, Cisternas, VM, Bourgeois, J, Hendley, JW \& Stauffer, P H 2005, 'Surviving a tsunami lessons from Chile, Hawaii and Japan’, US Department of the Interior, US Geological Survey Circular 1187, pp. 24.

Berkman, SC \& Symons, JN 1964, ‘The tsunami of 22 May, 1960 as recorded at tide stations', US Coast and Geodectic Survey Report, pp. 79.

Bilham, R, Engdahl, R, Fedl, N \& Satyabala, SP 2005, 'Partial and complete rupture of the IndoAndaman plate boundary 1847-2004’, Seismological Research Letters, vol. 76, pp. 299-311.

de Beer, JH 1983, 'Geophysical studies in the southern Cape Province and models of the lithosphere in the Cape Fold Belt', in Sönhge, APG \& Hälbich, IW (eds.), Geodynamics of the Cape Fold Belt, Special Publication Geological Society of South Africa, pp. 64-75.

de Beer, CH 1990, 'Structure of the Cape Fold Belt in the Ceres Syntaxis'. Geocongress Abstract, pp. 658-661.

de Swardt, AJJ \& Bennet, G 1974, 'Structural and physiographic development of Natal since the Late Jurassic’, Transactions of the Geological Society of South Africa, vol. 77, pp. 309-322.

Fernandez, LM. \& Shapira, A 1989, 'Maps of probabilities of earthquake occurrence in South Africa', Geological Survey, Pretoria.

Fujiwara, O \& Kamataki, T 2007, 'Identification of tsunami deposits considering the tsunami waveform: An example of subaqueous tsunami deposits in Holocene shallow bay on southern Boso Peninsula, Central Japan’, Sedimentary Geology, vol. 200, pp. 295-313.

Goedhart, ML, Woodborne, S \& Dondo, C 2007, 'Late Quaternary neotectonic reactivation of the Kango Fault, South Africa: Field estimate of extent and magnitude of surface rupture', Southern African Society for Quaternary Research (SASQUA) XVII Biennial Congress Abstracts, pp. 12.

Goff, JR, Chague-Goff, C \& Nichol, SL 2001, 'Palaeotsunami deposits: a New Zealand perspective', Sedimentary Geology, vol. 143, pp. 203-216.

Gokon, H, \& Koshimura, S 2012, 'Mapping of building damage of the 2011 Tohoku earthquake tsunami in Miyagi Prefecture’, Coastal Engineering Journal, vol. 54 no.1, pp. 243-273.

Grilli, ST \& Watts, P 2005, 'Tsunami generation by submarine mass failure. I: modelling, experimental validation, and sensitivity analyses', Journal of Waterway, Port, Coastal, and Ocean Engineering, vol. 131, pp. 283-297.

Hartnady, CJH 2005, 'Tsunami potential on East African coast, western Indian Ocean island states', Disaster Reduction in Africa - ISDR Informs, No. 5, pp. 22-24.

Indian Ocean Tsunami Warning and Mitigation System (IOTWS) 2007, 'Indian Ocean Tsunami Event Post-event assessment of IOTWS performance’, IOC Information Series, No. 77. pp. 99 pp.

Kijko, A, Midzi, V, Ramperthap, J \& Singh, M 2008, 'A probabilistic tsunami hazard assessment for coastal South Africa from distant tsunamogenic sources’, Council for Geoscience report, No. 2008-0156, pp. 40. 
Kruger, F \& Ohrnberger, M 2005, 'Spatio-temporal source characteristics of the 26 December 2004 Sumatra earthquake as imaged by teleseismic broadband arrays’, Geophysical Research Letters, vol. 32.

Liu, PL-F., Lynett, P, Fernando, H, Jaffe, B, Fritz, H, Higman, B, Morton, R, Goff, J \& Synolakis, C 2005, 'Observations by the international tsunami team in Sri Lanka', Science, vol. 308, pp. 1595.

Luger, SA 2010, 'Eskom Nucleur Sites Site Safety Reports: Numerical modelling of coastal processes Thyspunt’, Prestedge Retief Dresner Wijnberg (Pty) Ltd Report, no. 1010/2/102, pp. 173.

Luger, S, \& Harris, RL 2010, 'Modelling tsunami generated by earthquakes and submarine slumps using MIKE-21', in International MIKE by DHI conference, South Africa, no. P017.

Løvholt, F, Zamora, N, Glimsdal, S, Yetman, G \& Smebye, H 2009, 'Tsunamis', in Global Assessment Report on Disaster Risk Reduction Appendix I (Global Risk Analysis), pp. 31-36.

Mader, CL 1974, 'Numerical simulation of tsunamis', Journal of physical Oceanography, vol. 4 No. 1, pp, 74-82.

McCloskey, J, Antonioli, A, Piantenesi, A, Sieh, K, Steacy, S, Nalbant, S, Cocco, M, Giunchi, C, Huang, JD \& Dunlop, P 2008, 'Tsuami threat in the Indian Ocean from a future megathrust earthquake west of Sumatra’, Earth and Planetary Science Letters, vol. 265, pp. 61-81.

Minoura, K, Nayaka, S \& Uchida, M 1994, 'Tsunami deposits in a lacustrine sequence of the Sanriku coast, northeast Japan’, Sedimentary Geology, vol. 89, pp. 25-31.

Mori, N, Takahashi, T \& The 2011 Tohoku Earthquake Tsunami Joint Survey Group 2012, 'Nationwide post event survey and analysis of the 2011 Tohoku Earthquake Tsunami’, Coastal Engineering Journal, vol. 54 No. 1.

Morton, RA, Goff, JR \& Nichol, SL 2008, 'Hydrodynamic implications of textural trends in sand deposits of the 2004 tsunami in Sri Lanka', Sedimentary Geology, vol. 207, pp. 56-64.

Nichol, SL., Chague-Goff, C, Goff, JR., Horrocks, M, McFadgen, BG. \& Strotz, LC 2010, 'Geomorphology and accommodation space as limiting factors on tsunami deposition: Chatham Island, southwest Pacific Ocean’, Sedimentary Geology, vol. 229, pp. 41-52.

Okal, EA. \& Synolakis, CE 2004, 'Source discriminants for near-field tsunamis', Geophysics Journal International, vol. 158, pp. 899-912.

Okal, EA. \& Synolakis, CE 2008, 'Far-field tsunami hazard from mega-thrust earthquakes in the Indian Ocean’, Geophysical Journal International, vol. 172 no. 3, pp. 995-1015.

Okal, EA. \& Hartnady, CJH 2009, 'The South Sandwich Islands earthquake of 27 June 1929: seismological study and interference on tsunami risk for the South Atlantic', South African Journal of Geology, vol. 112, pp. 359-370.

Okal, EA., Fritz, HM \& Sladen, A 2009, '2004 Sumatra-Andaman tsunami surveys in the Comoro Islands and Tanzania and regional tsunami hazard from future Sumatra events', South African Journal of Geology, vol. 112 no. 3-4, pp. 343-358.

Okal, EA., Visser, JN, \& de Beer, CH 2014, 'The Dwarskersbos, South Africa local tsunami of August 27, 1969: field survey and simulation as a meteorological event', Natural Hazards, vol. 74 no. 1, pp. 251268. 
Partridge, TC \& Maud, RR 2000, 'Macro-scale geomorphic evolution of southern Africa', in: Partridge, TC \& Maud, RR (eds.) The Cenozoc of Southern Africa, Oxford Monographs on Geology and Geophysics, pp. 3-18.

Peters, R, Jaffe, B \& Gelfenbaum, G 2007, 'Distribution and sedimentary characteristics of tsunami deposits along the Cascadia margin of western North America’, Sedimentary Geology, vol. 200, pp. 372-386.

Piatanesi, A, \& Tinti, S 2002, 'Numerical modelling of the September 8, 1905 Calabrian (southern Italy) tsunami’, Geophysical Journal International, vol. 150 no. 1, pp. 271-284.

Pignatelli, C, Sanso, P, \& Mastronuzzi, G 2009, 'Evaluation of tsunami flooding using geomorphologic evidence', Marine Geology, vol. 260, pp. 6-18.

Rabinovich, AB \& Thomson, RE 2007, 'The 26 December 2004 Sumatra Tsunami: Analysis of tide gauge data from the World Ocean part 1. Indian Ocean and South Africa', Pure and Applied Geophysics, vol. 164, pp. 261-308.

Roberts, DL. 2008, 'Nuclear siting investigation programme: potential sources of tsunami along the South African coast', Council for Geoscience, no. 2008-0220, pp. 35.

Salzmann, L. and Green, A. 2012. Boulder emplacement on a tectonically stable, wave-dominated coastline, Mission Rocks, northern KwaZulu-Natal, South Africa. Marine Geology, vol. 323-325, 95-106.

Scheffers, A. and Kelletat, D. (2003). Sedimentologic and geomorphologic tsunami imprints worldwide a review. Earth-Science Reviews, 63, 83-92.

Shapira, A, Fernandez, LM \& du Plessis, A 1989, 'Frequency-magnitude relationships of southern African seismicity’, Tectonophysics, vol. 167 no. 2-4, pp. 261-271.

Shiki, T, Tsuji, Y, Yamazaki, T, 2008, ‘Tsunamiites: Features and Implicaions’, Elsevier B.V., pp. 411.

Synolakis, CE 1991, 'Tsunami runup on steep slopes: How good linear theory really is', in Tsunami Hazard, Springer Netherlands, pp. 221-234.

Tanioka, Y, \& Satake, K 1996, 'Tsunami generation by horizontal displacement of ocean bottom', Geophysical Research Letters, vol. 23 no.8, pp. 861-864.

Theron, JN 1974, 'The seismic history of the southwestern Cape Province', in: Ward, WL \& Kent, LE (eds.) The earthquake of 29 September 1969 in the southwestern Cape Province, South Africa, Seismological Series 4, Geological Survey Department of Mines, South Africa, pp. 9-26.

Thomas, RJ 1989, ‘A tale of two tectonic terranes’, South African Journal of Geology, vol. 93, pp. 306321.

Tinti, S, \& Armigliato, A 2003, 'The use of scenarios to evaluate the tsunami impact in southern Italy', Marine Geology, vol. 199 no. 3, pp. 221-243.

Titov, VV \& Synolakis, CE 1998, 'Numerical modelling of tidal wave runup', Journal of Waterway, Port, Coastal, and Ocean Engineering, vol. 124, pp. 157-171

U.S. NRC 2009, 'Tsunami Hazard Assessment at Nuclear Power Plant Sites in the United States of America’, Final Report. U.S. Nuclear Regulatory Commission, Report NUREG/CR-6966.

Van Dorn, WG 1987, 'Tide gauge response to tsunamis: Part II: Other Oceans and smaller Seas', Journal of Physical Oceanography, vol. 17, pp. 1507-1516. 
Weiss, R, \& Bahlburg, H 2006, 'A note on the preservation of offshore tsunami deposits', Journal of Sedimentary Research, vol. 76 no. 12, pp. 1267-1273.

\section{Websites}

National Oceanic and Atmospheric Administration (NOAA) Center for Tsunami Research (2011). URL: http://nctr.pmel.noaa.gov/model.html Date accessed: 13 January 2011.

National Oceanic and Atmospheric Administration (NOAA) National Geophysical Data Center (NGDC) (2011). URL: http://www.ngdc.noaa.gov/hazard/tsu.shtml Date accessed: 13 January 2011.

South African Weather Service (SAWS) (2008). www.weathersa.co.za Date accessed: 29 August 2008 by David L. Roberts.

United States Geological Survey (USGS) Earthquake Hazards Program (2011). http://earthquake.usgs.gov/earthquakes/world/world_density.php Date accessed: 27 February 2011. 